Portland State University

PDXScholar

\title{
Hedonic Modeling of Commercial Property Values: Distance Decay from the Links and Nodes of Rail and Highway Infrastructure
}

Kihwan Seo

Korea Research Institute for Human Settlements

Deborah Salon

Arizona State University

Michael Kuby

Arizona State University

Aaron Golub

Portland State University, agolub@pdx.edu

Follow this and additional works at: https://pdxscholar.library.pdx.edu/usp_fac

Part of the Transportation Commons, Urban Studies Commons, and the Urban Studies and Planning Commons

Let us know how access to this document benefits you.

\section{Citation Details}

Seo, Kihwan; Salon, Deborah; Kuby, Michael; and Golub, Aaron, "Hedonic Modeling of Commercial Property Values: Distance Decay from the Links and Nodes of Rail and Highway Infrastructure" (2018). Urban Studies and Planning Faculty Publications and Presentations. 220.

https://pdxscholar.library.pdx.edu/usp_fac/220

This Post-Print is brought to you for free and open access. It has been accepted for inclusion in Urban Studies and Planning Faculty Publications and Presentations by an authorized administrator of PDXScholar. Please contact us if we can make this document more accessible: pdxscholar@pdx.edu. 
Seo, Kihwan, Michael Kuby, Aaron Golub, and Deborah Salon. 2018. Hedonic modeling of commercial property values: distance decay from the links and nodes of rail and highway infrastructure. Transportation (doi.org/10.1007/s11116-018-9861-z).

\title{
Hedonic modeling of commercial property values: distance decay from the links and nodes of rail and highway infrastructure
}

\author{
Abstract This study investigates the impacts of positive and negative externalities of highways \\ and light rail on commercial property values in Phoenix, Arizona. We hypothesize that the \\ positive externality (i.e., accessibility) of highway and light rail accrues at exits and stations, \\ whereas nodes and links of highways and light rail emanate negative effects. Positive and \\ negative effects decay with increasing distance and are captured by multiple distance bands. \\ Hypotheses are tested using a spatial error regression model. Results show that commercial \\ property values are positively and significantly associated with the accessibility benefits of \\ transport nodes. The distance-band coefficients form a typical distance decay curve for both \\ modes with no detectable disamenity donut effect immediately around the nodes. Unexpectedly, \\ impacts of light rail stations extend farther than those of highway exits. Only the links of light \\ rail are negatively associated with property values, as hypothesized. When the sample is \\ subdivided by type of commercial property, the magnitude and distance extent of impacts are \\ surprisingly consistent, with light rail stations having stronger impacts than highway exits on all \\ three classes of commercial property: industrial, office, and retail and service. Rail links have a \\ significant negative relationship with price for all three types of commercial property, but \\ highways have a significant negative relationship only with industrial properties.
}

Keywords Highway $\cdot$ Light rail $\cdot$ Spatial error model $\cdot$ Node $\cdot$ Link $\cdot$ Commercial property value 


\section{Introduction}

Numerous studies have focused on transportation facilities as an important determinant of property values because they provide accessibility as well as nuisance effects that may alter property values (Vessali 1996; Bateman et al. 2001). While a considerable body of hedonic literature has investigated residential property values, fewer studies have addressed nonresidential or commercial property values (Weinberger 2001; Ryan 2005). Of these, even fewer have considered the impacts of multiple modes of transportation, such as rail and highway, and fewer still have attempted to disentangle the separate effects of transportation nodes and links in their models so that they can capture the distance decay of positive and negative impacts. Seo et al. (2014) built a hedonic price model with this comprehensive set of factors (i.e., distance decay around the nodes and links of highways and light rail transit) for residential property values in Phoenix, Arizona. This study extends that work to commercial properties.

The purpose of this study is to use the theoretical framework of Seo et al. (2014) to estimate the impacts of network nodes and links of both light rail and highways on commercial property values in Phoenix, AZ. The results of this study may offer guidance for locating commercial property to maximize accessibility and profit based on the distance from transportation infrastructure. This study may also inform policy makers on designing location value capture-based funding mechanisms for new public transport investments (Peterson 2009; Zhao et al. 2012). We employ a spatial hedonic regression approach, and subdivide commercial properties into office, industrial, and retail and service categories to test whether transportation facilities have dissimilar effects on the different types of commercial property. Hence, the specific research questions are: 
- How do commercial property markets value the positive and negative effects of proximity to highway compared with proximity to light rail?

- How do commercial property markets value amenities and disamenities of proximity to transport nodes compared with transport links?

- How do these positive and negative effects decay (or increase) with distance to transportation infrastructure?

- How do such effects vary by type of commercial property?

- How do the results for commercial property compare with Seo et al.'s (2014) results for residential property values in the same city and time period?

\section{Literature Review}

As noted earlier, the literature documenting transportation infrastructure impacts on residential property values is quite extensive. In contrast, a smaller body of literature exists on the determinants of commercial property values, and only a handful of studies focused on the transportation-related factors (Weinberger 2001; Ryan 2005; Billings 2011; Golub et al. 2012). Many studies focused mainly on the impacts of access to the central business district (CBD), but some of these studies also included transportation-related factors as explanatory variables (Clapp 1980; Brennan et al. 1984; Sivitanidou 1995; Sivitanidou 1996; Dunse and Jones 1998). Table 1 summarizes selected hedonic studies of commercial property values with regard to the transportation-related factors they considered:

- dependent variable (type of commercial property)

- amenity (accessibility) and disamenity (noise, traffic, air pollution, crime) or both

- distance decay of these effects

- $\operatorname{mode}(\mathrm{s})$ of transport studied 
- whether distance effects are measured from the nodes or links of the network

- time frame (single- or multi-year)

Table 1 Summary of selected literature on road and rail impacts in hedonic price models for commercial properties

\begin{tabular}{|c|c|c|c|c|c|c|c|c|}
\hline \multirow[t]{2}{*}{ Authors } & \multirow[t]{2}{*}{$\begin{array}{l}\text { Dependent } \\
\text { Variable }\end{array}$} & \multirow[t]{2}{*}{ Study Focus } & \multirow[t]{2}{*}{$\begin{array}{l}\text { Distance } \\
\text { Measure }\end{array}$} & \multicolumn{2}{|c|}{$\begin{array}{l}\text { Transport } \\
\text { Mode }\end{array}$} & \multicolumn{2}{|c|}{$\begin{array}{l}\text { Network } \\
\text { Element }\end{array}$} & \multirow[t]{2}{*}{$\begin{array}{l}\text { Time } \\
\text { frame }\end{array}$} \\
\hline & & & & Road & Rail & Links & Nodes & \\
\hline $\begin{array}{l}\text { Damm et al., } \\
1980\end{array}$ & $\begin{array}{l}\text { Assessed } \\
\text { landvalues } \\
\text { (Retail) }\end{array}$ & Accessibility & $\begin{array}{c}\text { Actual } \\
\text { distance } / 0.1 \\
\text { mile dummy }\end{array}$ & & $\mathrm{O}$ & & $\mathrm{O}$ & $\begin{array}{c}\text { Multi- } \\
\text { year } \\
(1969- \\
1976)\end{array}$ \\
\hline $\begin{array}{l}\text { Landis and } \\
\text { Loutzenheiser } \\
1995\end{array}$ & $\begin{array}{l}\text { Asking rents } \\
\text { (Office) }\end{array}$ & Accessibility & $\begin{array}{c}\text { Multi-band } \\
(200 \mathrm{~m} \text { bands } \\
\text { up to } 1 / 2 \text { mile) }\end{array}$ & & $\mathrm{O}$ & & $\mathrm{O}$ & $\begin{array}{l}\text { Single- } \\
\text { year } \\
(1993)\end{array}$ \\
\hline $\begin{array}{l}\text { Sivitanidou } \\
1995\end{array}$ & $\begin{array}{l}\text { Effective rents } \\
\quad \text { (Office) }\end{array}$ & Accessibility & $\begin{array}{c}\text { \# of passing } \\
\text { highway/Actual } \\
\text { distance from } \\
\text { Airport }\end{array}$ & $\mathrm{O}$ & Airport & & $\mathrm{O}$ & $\begin{array}{l}\text { Single- } \\
\text { year } \\
(1990)\end{array}$ \\
\hline $\begin{array}{l}\text { Sivitanidou } \\
1996\end{array}$ & $\begin{array}{c}\text { Assessed } \\
\text { property values } \\
\text { (Office) }\end{array}$ & Accessibility & Actual distance & $\mathrm{O}$ & & $\mathrm{O}$ & & $\begin{array}{c}\text { Single- } \\
\text { year } \\
(1992)\end{array}$ \\
\hline $\begin{array}{l}\text { Bollinger et } \\
\text { al., } 1998\end{array}$ & $\begin{array}{l}\text { Asking rents } \\
\text { (Office) }\end{array}$ & Accessibility & $\begin{array}{c}\text { Single-band } \\
\text { (1/4 mile for } \\
\text { rail transit, } 1 \\
\text { mile for Hwy) }\end{array}$ & $\mathrm{O}$ & $\mathrm{O}$ & & $\mathrm{O}$ & $\begin{array}{c}\text { Multi- } \\
\text { year } \\
(1990, \\
1994, \\
1996)\end{array}$ \\
\hline $\begin{array}{l}\text { Weinberger } \\
2001\end{array}$ & $\begin{array}{c}\text { Effective rents } \\
\text { (Commercial } \\
\text { whole) }\end{array}$ & Accessibility & $\begin{array}{c}\text { Multi-band (1/4 } \\
\text { mile bands for } \\
\text { rail \& } 1 \text { mile } \\
\text { bands for Hwy) }\end{array}$ & $\mathrm{O}$ & $\mathrm{O}$ & & $\mathrm{O}$ & $\begin{array}{l}\text { Multi- } \\
\text { Year } \\
(1984- \\
2000)\end{array}$ \\
\hline $\begin{array}{l}\text { Cervero and } \\
\text { Duncan } 2002\end{array}$ & $\begin{array}{l}\text { Assessed land } \\
\text { values } \\
\text { (Commercial } \\
\text { whole) }\end{array}$ & Accessibility & $\begin{array}{c}\text { Single-band } \\
(1 / 4 \text { mile for } \\
\text { rail \& } 1 / 2 \text { mile } \\
\text { for Hwy })\end{array}$ & & $\mathrm{O}$ & & $\mathrm{O}$ & $\begin{array}{c}\text { Two- } \\
\text { year } \\
(1998- \\
1999)\end{array}$ \\
\hline Ryan 2005 & $\begin{array}{c}\text { Asking rents } \\
\text { (Office/ } \\
\text { Industrial) }\end{array}$ & Accessibility & Actual distance & $\mathrm{O}$ & $\mathrm{O}$ & & $\mathrm{O}$ & $\begin{array}{c}\text { Multi- } \\
\text { year } \\
(1986- \\
1995)\end{array}$ \\
\hline Billings 2001 & $\begin{array}{c}\text { Sale Prices } \\
\text { (Commercial } \\
\text { whole) }\end{array}$ & Accessibility & $\begin{array}{c}\text { Single band } \\
(1 \text { mile for } \\
\text { rail)/Actual } \\
\text { distance (Hwy) }\end{array}$ & $\mathrm{O}$ & $\mathrm{O}$ & & $\mathrm{O}$ & $\begin{array}{l}\text { Multi- } \\
\text { year } \\
(1994- \\
2008)\end{array}$ \\
\hline $\begin{array}{l}\text { Golub et al., } \\
2012\end{array}$ & $\begin{array}{c}\text { Sale Prices } \\
\text { (Commercial } \\
\text { whole) }\end{array}$ & $\begin{array}{l}\text { Accessibility } \\
\text { \&disamenity }\end{array}$ & Actual distance & & $\mathrm{O}$ & $\mathrm{O}$ & $\mathrm{O}$ & $\begin{array}{l}\text { Multi- } \\
\text { year } \\
(1988-\end{array}$ \\
\hline
\end{tabular}




\begin{tabular}{|c|c|c|c|c|c|c|c|c|}
\hline & & & & & & & & 2010) \\
\hline This study & $\begin{array}{c}\text { Sale Prices } \\
\text { (Commercial } \\
\text { Whole/Office/ } \\
\text { Industrial /Retail) }\end{array}$ & $\begin{array}{l}\text { Accessibility } \\
\text { \&disamenity }\end{array}$ & Multi-band & $\mathrm{O}$ & $\mathrm{O}$ & $\mathrm{O}$ & $\mathrm{O}$ & $\begin{array}{l}\text { Multi- } \\
\text { year } \\
(2000- \\
2014)\end{array}$ \\
\hline
\end{tabular}

Hedonic studies of commercial property use a variety of dependent variables, based at least partly on data availability (i.e., sales transaction data, actual transacted rents or effective rents, asking rents, and assessed property or land values). Although actual transacted sales prices are preferred (Ihlanfeldt and Martinez-Vazquez 1986) because they capture the real property market behaviors, commercial property sales prices or effective rents are hard to obtain because these data are often not open to public use (Mills 1992; Wheaton and Torto 1994; Landis and Loutzenheiser 1995; Bollinger et al. 1998). The majority of studies utilized asking rents, which were usually provided by large commercial real-estate consulting or brokerage firms such as CoreLogic, Coldwell Banker, and TRI Commercial Real Estate Services for academic research (Mills 1992; Landis and Loutzenheiser 1995; Bollinger et al. 1998; Ryan 2005). The use of asking rents is supported by Glascock et al. (1990), who found an extremely close relationship between effective rents and asking rents. However, both actual transacted rents and asking rents from the databases of commercial real estate service firms may yield biased samples. For instance, some databases of commercial real estate firms are limited to a specific size of office spaces (Landis and Loutzenheiser 1995). Moreover, sometimes the number of cases was too small for estimating a model (Dunse and Jones 1998; Nelson 1982). Brennan et al. (1984) used actual transacted office rents as a dependent variable with only 29 cases. Several studies used multi-year data, adjusted for real-estate price inflation, as a way to increase the sample size (Billings 2001; Golub et al. 2012). 
As an alternative, several studies of commercial properties used assessed values as the dependent variable, which has the advantage of representing the entire population of properties, thus reducing sampling error (Champ et al. 2003). Sivitanidou (1996) found significant spatial collinearity in the prices of transacted properties, which led her to report results based on a larger number of properties for which she had assessor valuations. A correlation of 0.98 between sales prices and assessed values provided evidence that in this case, assessed values were likely representative of market values. Transit-related hedonic research by Cervero and Duncan (2002) used estimated land values, which were apportioned from total taxable property values including improvements by the county assessor's office. They argued that there is no evidence that estimated land values are biased in a certain direction. However, despite these advantages, the use of assessed property value as the dependent variable is still problematic because the way some assessor offices estimate property values is similar to hedonic regression (Arizona Department of Revenue 2009), making circular reasoning a concern.

In addition, most studies have considered only one type of commercial property, such as office property (Landis and Loutzenheiser 1995; Dunse and Jones 1998), industrial property (Sivitanidou and Sivitanides 1995), or retail property (Damm et al, 1980). In contrast, Ryan (2005) studied two types of commercial properties (i.e. office and industrial properties), while others have analyzed commercial property as a whole (Cervero and Duncan 2002; Golub et al, 2012). Effects may differ across commercial property categories: in Ryan's 2005 study, while highway accessibility had a positive influence on office property values, neither highway nor light rail transit had a significant relationship with industrial property values. Thus, one should consider estimating impacts on both commercial property as a whole and each type of commercial property separately. 
Most previous studies of the relationship between transportation infrastructure and commercial property value focused on testing hypotheses related to the positive effects of accessibility (Damm et al. 1980; Landis and Loutzenheiser 1995; Sivitanidou 1995; Bollinger et al. 1998; Ryan 2005). Only one study took nuisance effects into consideration for commercial property (Golub et al. 2012). If a study does not consider nuisance effects but considers only positive effects with respect to the transportation infrastructure located in the study area, it may cause omitted variable bias (Nelson 1982; Champ et al. 2003; Debrezion et al. 2007). While some may argue that nuisance effects have no influence on the commercial property values, any factor that may have an impact on property values should be tested (Damm et al. 1980). Accessibility of commercial properties to transportation nodes and/or links has been measured in several different ways in previous studies:

- Euclidean distance (Sivitanidou 1996; Ryan 2005; Golub et al. 2012)

- a single Euclidean distance band as the impact zone (Bollinger et al. 1998; Cervero and Duncan 2002)

- multi-band distance (Landis and Loutzenheiser 1995; Weinberger 2001)

- mixed measurement methods such as Euclidean distance for highway exits and a singleband distance for the rail stations (Damm et al. 1980), a multi-band distance for light rail transit stations and a single-band distance for highway exits (Sivitanidou 1995)

- number of passing highways within the study area (Weinberger 2001)

How a researcher operationalizes distance as a proxy for transportation accessibility in a regression model is a critical decision. Ideally, the method should capture the impacts of accessibility on property values in terms of geographical extent with non-linearity. The method should also capture the net effects of accessibility and disamenities (De Vany 1976). The multi- 
band approach is a way of capturing a non-linear relationship between price impacts and distance from a transportation network. In a study of residential values, Seo et al. (2014) captured the benefits of nodes of highways using 400-meter bands up to 3200 meters and for light rail using 300-meter bands up to 3000 meters. The benefit peaked in the 400-meter band from the highway exits and the 300-meter band from the light rail stations, which were the closest distance bands for both modes. In another study of residential values, Salon et al. (2014) captured the benefits of nodes of the bus rapid transit (BRT) and the Metro rail using multiple distance bands in Guangzhou, China. They found no disamenity effect for Metro stations, but substantial disamenity effect for properties closest to the BRT. In contrast, Cervero and Duncan (2002) showed that commercial land values within a half mile of a highway interchange are unexpectedly penalized by being too close to the highway access points. These results confirm the usefulness of a multiple bands approach for determining the potential non-linear decay of the net effects of transportation infrastructure on commercial property values.

As shown in Table 1, only Golub et al. (2012) included proximity to network links as a disamenity variable in a hedonic model for commercial properties. To the best of our knowledge, there have been no studies that analyzed both nodes and links of both highways and rail transit for all types of commercial property values (i.e. office, industrial, retail and service properties), though some studies dealt simultaneously with nodes of both modes (Bollinger et al. 1998; Weinberger 2001; Billings 2001; Ryan 2005).

The values of surrounding properties are known to influence property values, including for commercial property. This kind of external neighborhood effect is known as spatial dependence or spatial autocorrelation. These spatial effects can be present in both the dependent variable and the error term of a regression model. To incorporate external neighborhood effects, 
researchers are increasingly testing and adjusting for spatial dependence using alternative geostatistical approaches (e.g. spatial lag and/or error models) for residential hedonic models (Partridge et al. 2012). Spatial approaches, however, do not seem to be common yet in commercial hedonic models. Bollinger et al. (1998) is the only commercial study we found that tested for spatial dependence, but they found no evidence of spatial effects using the Cliff-Ord test. Nevertheless, testing for spatial dependence is important, because hedonic modeling with spatial dependence in the dependent variable produces inconsistent estimates, while spatial dependence in the error term causes inefficient parameter estimates (LeSage and Pace 2009; Anselin 1988).

Based on this review of the hedonic literature, we reach a number of conclusions about how to analyze the amenity and disamenity effects of transportation infrastructure on commercial property values. First, the ideal dependent variable is the actual transacted sale prices of commercial property. Second, in addition to analyzing commercial property as a whole, it is valuable to subdivide the sample into types of commercial property if the sample size in each category is large enough. Third, the study method should allow for the possibility of both accessibility and nuisance effects of transportation infrastructure. Fourth, the multiple bands approach is well suited to determine the geographical extent of impacts of transportation investments and network nodes. Fifth, both highways and rail transit should be included simultaneously if both modes exist in the study area. Sixth, multi-year data can be used to secure enough observations. Seventh, the presence or absence of spatial dependence should be tested explicitly. 


\section{Theoretical Framework}

As a theoretical framework, this study incorporates the seven factors identified above by adopting the net effects model of Seo et al. (2014) for highways and light rail transit, which was expanded from De Vany's (1976) theoretical net effects model for airports. The theoretical model shown in Figure 1 is based on the following underlying hypotheses (Seo et al. 2014). First, the positive impact of accessibility should accrue only to the nodes of a rail or freeway network and decay from there, because travelers can only access the network at the stations and highway entrances. Second, the negative impact of disamenities such as noise, crime, pollution, or traffic should have a more limited spatial impact that decays more steeply with distance from both the network nodes and links than the positive benefits of accessibility. Third, network nodes should therefore exhibit net effects resulting from the sum of the positive and negative impacts, while the effect of links should be only negative. Lastly, highway exits should generate a more gradual decay and extended range than rail stations because of the different travel speeds of their dominant modes of access (motorized vs. non-motorized). 

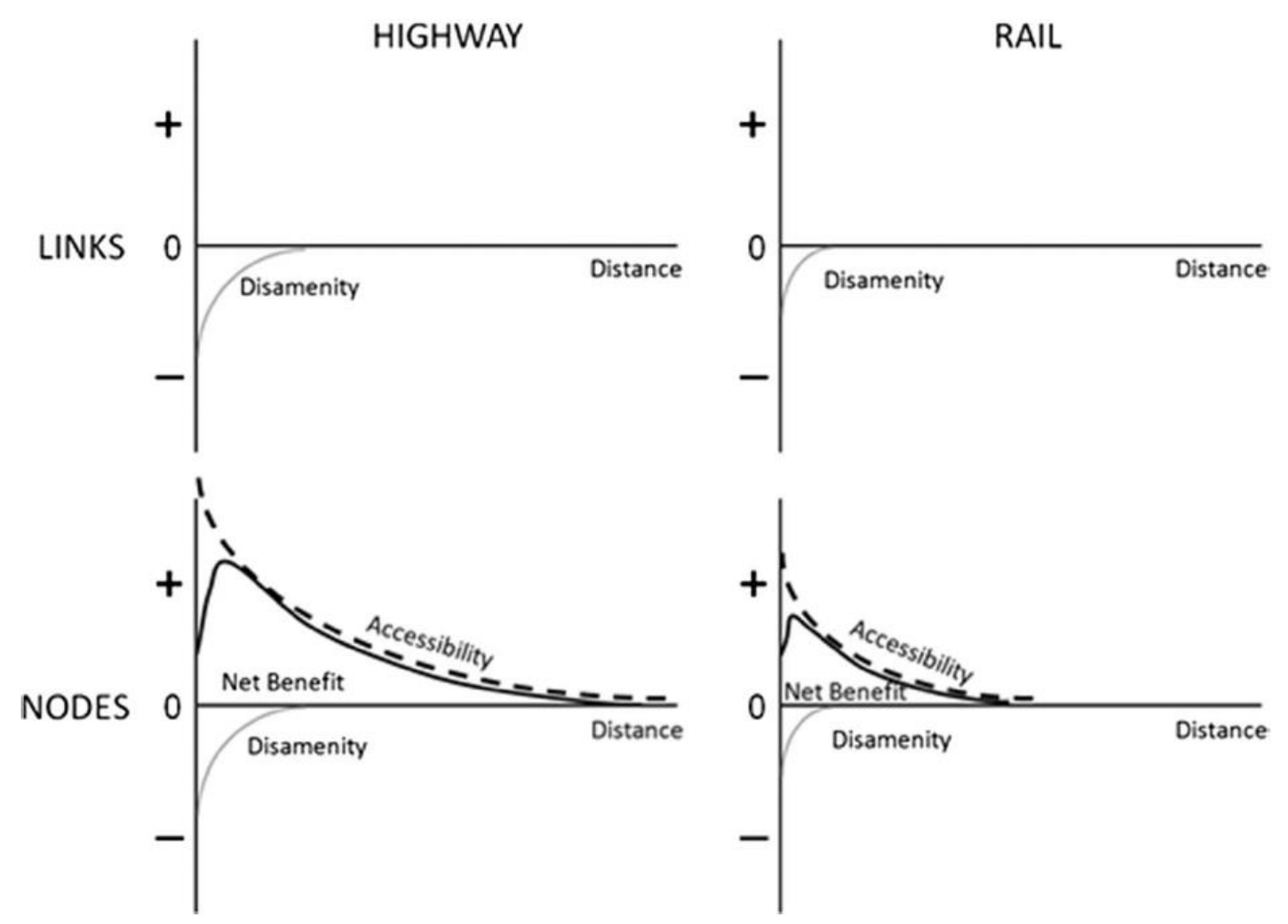

Figure 1 Conceptual framework for net benefit of combined impacts of accessibility and disamenities (source: Seo et al. 2014 - modified for commercial property)

In Seo et al. (2014), this theory was tested on residential property values in Phoenix, Arizona. For highway exits, benefits peaked at the closest distance (400m) from a highway exit, and decreased steadily from there, but the magnitude of impacts was small in general. For light rail stations, the coefficients were again positive for homes close to a station, peaked within $300 \mathrm{~m}$, and gradually decreased from there. Unexpectedly, the hypothesized "donut" effects around nodes were not evident in the results for either mode for residential property. The proximity to nodes of highways and light rail were highly statistically significant at the level of 0.001, while the proximity to links of highways and light rail were not significant even at the level of 0.1. This companion paper tests this model on commercial property. 
Theoretically, we might expect some differences between the effects on residential and commercial property. First, nuisance effects on commercial property are hypothesized to be less negative compared with residential property because activities on commercial property may themselves cause a considerable amount of noise nuisance (e.g., mechanical noise from industrial property, customer-caused traffic and noise from retail and service properties). Second, commercial activities take place in the daytime when noise is more acceptable. Third, crowds near transportation nodes that may generate nuisances can be favorable to commercial property but not to residential property markets. Thus, we hypothesize that the peaks of the net benefit curves in Figure 1 for commercial property should be skewed more to the left and lack any discernable donut effect.

Commercial property can be subdivided into office, industrial, and retail/service categories, and the impacts of transportation infrastructure are likely to vary by type (Ryan 1995). According to industrial location theory, transportation cost of inputs and outputs is one of the most important factors with labor cost and agglomeration economies (Weber 1929). Thus, for industrial property, it may be more important to locate for minimizing transportation cost of shipping products and materials rather than to be near light rail stations ${ }^{1}$. On the other hand, office property generally does not ship much in the way of materials and/or products, but employees and customers benefit from light rail access for commuting and service. Hence, we hypothesize that office property will put a higher premium on locating near light rail stations and highway exits to minimize transportation costs of both customers and employees. Lastly, retail and service properties need easy access for their employees and customers to minimize labor cost and maximize profits. Thus, retail and service properties may be willing to pay more to be

\footnotetext{
${ }^{1}$ However, if a freight rail network exists in the study area, industrial property may be found near freight rail stations to reduce transport cost of inputs and outputs based on the traits of industry.
} 
located near highway exits and light rail transit stations. In addition, retail and service properties may prefer to locate in or near a shopping mall for multi-purpose shopping agglomeration economies.

\section{Methods}

This paper extends the methodology developed by Seo et al. (2014) for residential property to commercial property. This methodology utilizes hedonic regression analysis to capture the relationships between proximity of transportation infrastructure and commercial property values while controlling for other determinants of value. To select a suitable functional form, scatter plots for the variables and log-transformed variables were analyzed for linearity, and the Akaike Information Criterion (AIC) and Bayesian Information Criterion (BIC) were examined to compare relative quality of models. To avoid multicollinearity, the Variance Inflation Factor (VIF) was also examined, and VIF values for our final model results are included in our Appendix tables. For the goodness of fit, adjusted $\mathrm{R}^{2}$ values were compared. Consequently, we selected the double-log functional form, which has an advantage in estimating price elasticities. It is expressed as:

$\ln P_{i}=\alpha+\beta_{1} \ln S_{i}+\beta_{2} \ln N_{i}+\beta_{3} \ln L_{i}+\beta_{4} D_{i}+\beta_{5} Q_{i}+\varepsilon_{\mathrm{i}}$

where $P_{\mathrm{i}}$ is the price of commercial property $i ; \alpha$ is a constant; $S_{\mathrm{i}}$ are structural characteristics for property $i ; N_{\mathrm{i}}$ are neighborhood characteristics for property $i ; L_{\mathrm{i}}$ are locational characteristics for property $i ; D_{i}$ are distance band dummies for property $i$, and $Q_{i}$ are quarterly dummies representing the year and quarter time of sale; and $\beta_{1}, \beta_{2}, \beta_{3}, \beta_{4}, \beta_{5}$ represent the coefficients of $S_{i}, N_{i}, L_{i}, D_{i}$, and $Q_{i}$ respectively; and $\varepsilon_{\mathrm{i}}$ is random error for property $i$. Quarterly time 
dummy variables are included to correct for fluctuations in the real estate market, important because the dataset spans a period of substantial market movement: 2009-2014.

Spatial effects were tested with the Lagrange Multiplier (LM) statistic using spatial weight matrices (Anselin and Rey 2014). To identify and select a suitable spatial regression model, we tested both contiguity (i.e. rook and queen contiguity using Thiessen polygons) and distance-based spatial weighting approaches (i.e. k-nearest neighbor or the Euclidean distance using property points data). These were compared using pseudo $\mathrm{R}^{\mathbf{2}}$ and Lagrange Multiplier test results and the model with the spatial weight matrix using the Euclidean distance approach was selected. The LM error test value of $437.462(p=.000)$ confirmed the presence of spatial dependence in the error term, while the LM lag test value of $2.604(p=.11)$ rejected the presence of spatial dependence in the dependent variable. The Koenker-Bassett test value of $376.639(p=$ .000) confirmed the heteroscedasticity in the dataset. Thus the spatial error model with heteroscedasticity option was selected for this study. Equation (2) and (3) provide the general forms of spatial error model:

$P=\alpha+\beta X+\varepsilon$

$\varepsilon=\lambda \mathrm{W} \varepsilon+\mu$

where $P$ is a vector of property sales prices; $\alpha$ is the constant term; $\beta$ is the $n \times 1$ vector of the coefficients of the explanatory variables; $\varepsilon$ is the $n \times 1$ vector of spatially autoregressive errors; $\lambda$ is the coefficient on the spatially lagged error; $W \varepsilon$ is the spatially lagged portion of the error; and $\mu$ is an independent but heteroscedastically distributed error. Regression analyses were carried out separately for commercial property as a whole, office property, industrial property, 
and retail and service properties because impacts of the proximity of highways and LRT may differ by type of commercial market.

\section{Study Area and Data}

\section{Study Area}

We studied the City of Phoenix, Arizona because one of the study purposes is to compare the results for commercial property to Seo et al. (2014)'s residential property model. The City of Phoenix is the center of commercial property markets in the Greater Phoenix Area, where most of the high-rise office buildings are located (Figure 2). Phoenix is also the most active industrial property market in the Greater Phoenix Area (Colliers International 2015). As of 2014 there were 47,882 commercial property parcels within the city limits, excluding those properties categorized as commercial but used for residential purposes (e.g. apartment, condos, and multifamily homes). 


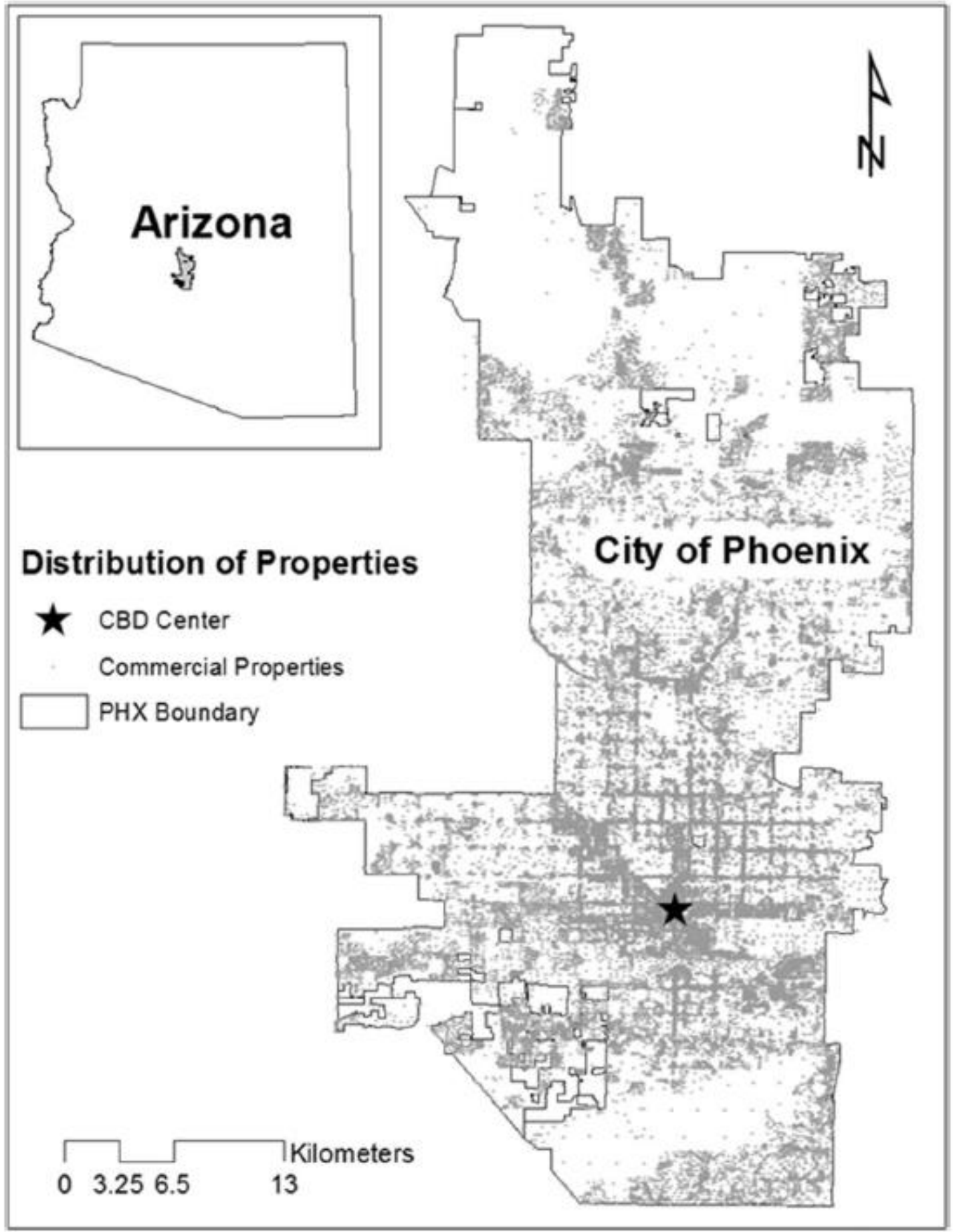

Figure 2 Study area and distribution of all commercial properties 
Phoenix relies on an automobile-centered transportation system built around wellconnected highways and grid-style arterials. Although there are numerous strong commercial centers across the city, downtown Phoenix is the original core of the city and many cultural, commercial, and governmental activities are still concentrated there. Light rail transit opened in 2008 and runs east and north of Phoenix's central business district (CBD) through job-rich corridors. Freeways encircle the CBD and extend east, west, and north from downtown. Phoenix Sky Harbor Airport is one of the most centrally located major airports in the United States, just a few miles east of the CBD and connected to the light rail by an elevated, automated rubber-tired people mover. Thus, many commercial properties are located along these arterials, highways, and light rail networks and especially near the CBD and airport. In terms of noise disamenities, commercial properties along the highways are not protected by sound walls, whereas all the residential properties are protected by sound walls or earth berms.

\section{Data}

Commercial property sales data were obtained from the Maricopa County Assessor's Office for use as the dependent variable for this study. This dataset contains sale prices and dates for commercial properties that were sold between 2009 and 2014, as well as structural characteristics such as parcel size, total interior area, a number of stories, building condition, and construction year. Initially, 8,159 commercial properties were extracted from the Assessor's 2015 data. We first removed 3,280 commercial properties that are used for residential purposes. We also removed some commercial properties that sold for less than $\$ 50,000$, which we considered outliers. We also removed properties with insufficient information. Lastly, we found many cases of duplicated prices for groups of neighboring properties sold as a bundle with a single combined sale price. Rather than delete them from the study, we assigned a proportional sale price to each 
parcel based on limited property value $(\mathrm{LPV})^{2}$ for each member parcel provided by Assessor's office.

The remaining 3,337 observations were further divided into 1,150 office properties, 357 industrial properties, and 1,830 retail and service properties. Because this analysis focuses on the relationships between property values and their proximity to infrastructure, we would be concerned about sample bias if the spatial distribution of our transacted sample were clearly different from that of all commercial properties in Phoenix. Visual inspection of a map of these transacted properties reveals that their spatial distribution looks much like that of all commercial properties in the City of Phoenix, providing confidence that this sample is not spatially biased. The tract-level median household income and population density were obtained from the 2010 U.S. Census Bureau to represent neighborhood characteristics. Locational characteristics such as Euclidean distance to Sky Harbor Airport, shopping malls, and major arterials were measured using ArcGIS 10.2.2 software and readily available GIS datasets (see Table 2 for summary of variables).

Table 2 Summary of variables (Observations $=3,337$ )

\begin{tabular}{|c|c|c|c|c|c|}
\hline Variable & Description & Mean & S.D. & Min & Max \\
\hline \multicolumn{6}{|c|}{ Dependent variable } \\
\hline Property Price & Sale price $(\$ 1000 \mathrm{~s})$ & 1,572 & 4,306 & 50 & 66,600 \\
\hline \multicolumn{6}{|c|}{ Structural variables } \\
\hline Lot Size & Parcel size (1000 sqft) & 82 & 266 & 0.2 & 6,974 \\
\hline Interior SqFt & Total interior area (1000 sqft) & 34 & 84 & 0 & 1,267 \\
\hline Stories & Number of stories & 1 & 1 & 1 & 22 \\
\hline Age & Age of property (years) & 28 & 20 & 0 & 123 \\
\hline \multicolumn{6}{|c|}{ Neighborhood variables } \\
\hline Median Income & Median household income $(\$ 1000$ s) & 44 & 22 & 10 & 152 \\
\hline $\begin{array}{l}\text { Population } \\
\text { Density }\end{array}$ & Population density (per km²) & 1,606 & 1,132 & 74 & 9,052 \\
\hline
\end{tabular}

\section{Locational variables}

\footnotetext{
${ }^{2}$ The limited property value is a unique approach that is used to calculate primary tax in Arizona.
} 


\begin{tabular}{llrrrr} 
Dist Airport & Distance from airport (m) & 11,913 & 6,434 & 952 & 36,314 \\
Dist Mall & Distance from nearest shopping mall (m) & 2,370 & 1,501 & 6 & 8,436 \\
Dist Arterial & Distance from nearest arterial road (m) & 175 & 177 & 19 & 1,327 \\
\hline
\end{tabular}

To develop the best model for testing the transportation amenity/disamenity hypotheses, many different distance measurements in terms of distance bands and maximum range were tested (Table 3 and Figure 3 for multiple distance band approach). The nearest distance function in GIS was used to create the variables representing distances to nodes and links. Specifically, the distance from the nearest node and link to each property was calculated, and this distance was then put into one distance "bin" variable in each category. Thus, although a property might be in the catchment area for multiple light rail stations or highway exits, our variables indicate distance to the closest station, rail, exit, and highway.

Distances from highway links were measured in three bands, out to $350 \mathrm{~m}$ as the noise disamenity zone (Nelson 1982). ${ }^{3}$ The distance from a highway exit to each commercial property was measured in three $300 \mathrm{~m}$ bands, out to $900 \mathrm{~m}$. The distance from LRT stations to individual commercial properties was measured in four $300 \mathrm{~m}$ bands, out to $1200 \mathrm{~m}$, and distances from the light rail track were measured in $100 \mathrm{~m}$ bands, out to $300 \mathrm{~m}$. Additionally, farther out distance bands were tested, but dropped due to high correlation with other factors.

\footnotetext{
${ }^{3}$ In Nelson (1982)'s review paper, 300m or 1000feet is considered as a noise zone. However, we used 350m as the impact zone because highway centerline was used to measure distance. Thus three multiple bands are $0-150 \mathrm{~m}, 150$ $250 \mathrm{~m}$, and $250-350 \mathrm{~m}$.
} 


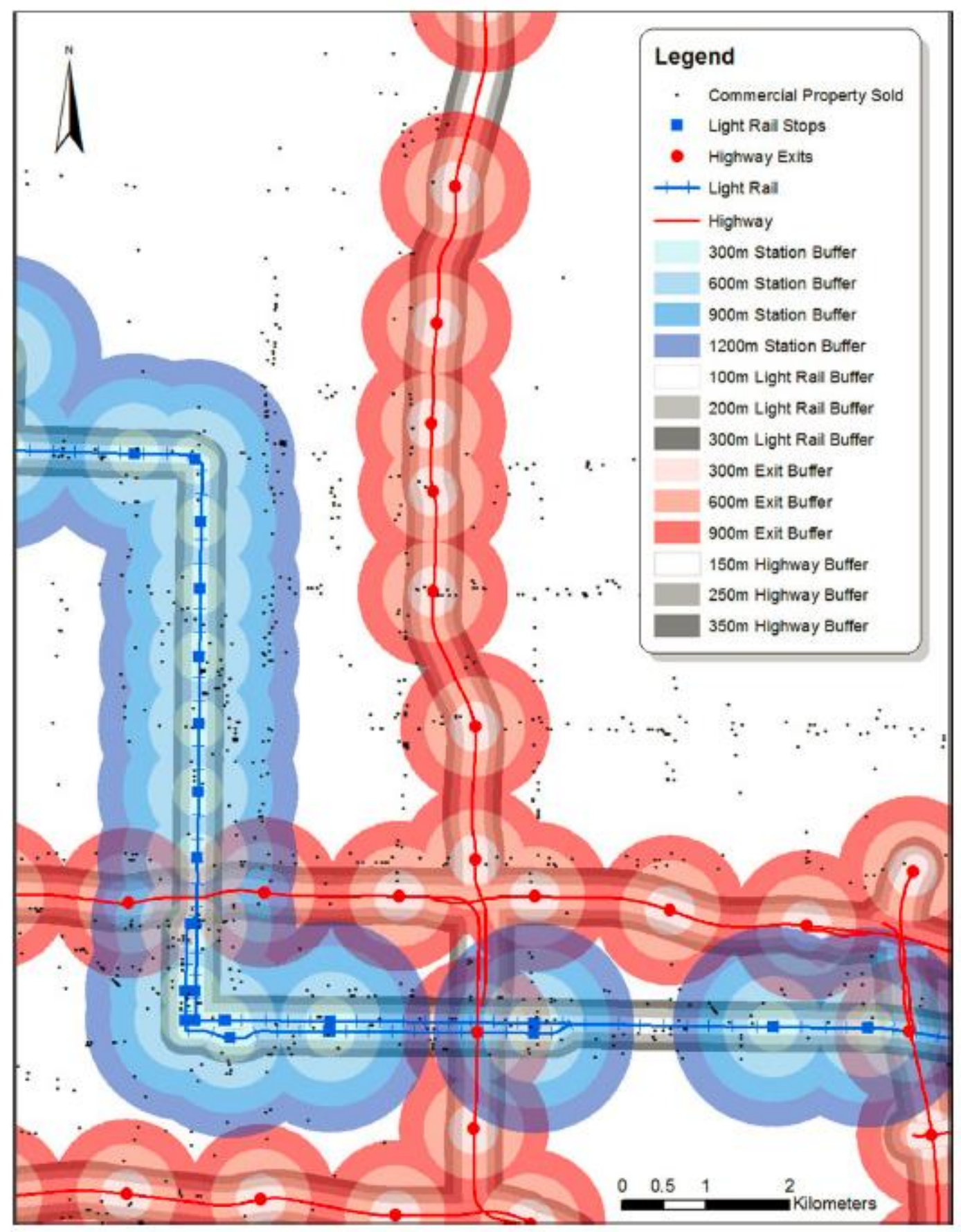

Fig. 3 Section of central Phoenix illustrating of multiple distance band approach around light rail links and stations and freeway links and exits. When rings around nearby stations and exits overlap, commercial properties are assigned to the distance band of their closest station. Note that some properties fall into a distance band for each of the four types of transport infrastructure where light rail lines cross highways and stations and exits are located nearby

Table 3 Percentage of observations in distance dummy variables

Dummy variable Description




\begin{tabular}{llr}
\hline Exit $300 \mathrm{~m}$ & Less than 300m from highway exit & 5.5 \\
Exit $600 \mathrm{~m}$ & 300-600m from highway exit & 14.9 \\
Exit $900 \mathrm{~m}$ & 600-900m from highway exit & 15.7 \\
Station $300 \mathrm{~m}$ & Less than 300m from light rail station & 2.5 \\
Station $600 \mathrm{~m}$ & 300-600m from light rail station & 4.5 \\
Station $900 \mathrm{~m}$ & 600-900m from light rail station & 3.4 \\
Station $1200 \mathrm{~m}$ & 900-1200m from light rail station & 3.2 \\
Hwy $150 \mathrm{~m}$ & Less than 150m from highway link & 4.8 \\
Hwy $250 \mathrm{~m}$ & 150-250m from highway link & 6.4 \\
Hwy $350 \mathrm{~m}$ & 250-350m from highway link & 5.4 \\
Light Rail $100 \mathrm{~m}$ & Less than 100m from light rail track & 2.8 \\
Light Rail $200 \mathrm{~m}$ & 100-200m from light rail track & 1.3 \\
Light Rail $300 \mathrm{~m}$ & 200-300m from light rail track & 1.5 \\
\hline
\end{tabular}

\section{Results}

\section{All Commercial Property}

Table 4 shows the coefficients, significance levels, Pseudo $R^{2}$, and Lambda $(\lambda)$ for the spatial error models for all commercial properties and for three commercial property submarkets (see Appendix Tables 5 to 8 for details on these estimates, comparison to OLS estimates, and VIF values). ${ }^{4}$ The Pseudo $\mathrm{R}^{2}$ and adjusted $\mathrm{R}^{2}$ values are extraordinarily high (above 0.9 in all cases), in part because we include quarterly time dummy variables to control for real estate market fluctuations.

Control variables are highly statistically significant and their estimated coefficient signs are as expected. Lot size, interior square footage, and building height (stories) are all positively associated with price, while building age has a negative association with price. Both median household income and population density are positively associated with price. Proximities to the airport, shopping malls, and arterial streets are positively associated with the price, and all are statistically significant except in the industrial property model. Given that Sky Harbor Airport

\footnotetext{
${ }^{4}$ Hedonic models were estimated with and without the 2009 data because of the sharp fluctuations of the real estate market caused by financial crisis. Results, however, did not differ substantially, and therefore the final results include all years of data.
} 
begins just 24 city blocks east of downtown Phoenix, the Airport proximity variable in our model also captures some of the effect of distance from the CBD. Therefore, this control variable should not be interpreted as purely an airport effect. ${ }^{5}$

Table 4 Estimation results for all commercial properties and three submarkets

\begin{tabular}{|c|c|c|c|c|}
\hline \multirow[b]{2}{*}{ Variable } & $\begin{array}{l}\text { All } \\
\text { commercial } \\
(\mathrm{N}=3,337)\end{array}$ & $\begin{array}{l}\text { Industrial } \\
(\mathrm{N}=357)\end{array}$ & $\begin{array}{l}\text { Office } \\
(\mathbf{N}=\mathbf{1 , 1 5 0})\end{array}$ & $\begin{array}{l}\text { Retail \& } \\
\text { Service } \\
(\mathbf{N}=\mathbf{1 , 8 3 0}) \\
\end{array}$ \\
\hline & Coef & Coef & Coef & Coef \\
\hline (Constant) & $3.955 * * *$ & $3.811 * * *$ & $4.186 * * * *$ & $3.968 * * *$ \\
\hline \multicolumn{5}{|l|}{ Structural Variables $\left(S_{\mathrm{i}}\right)$} \\
\hline Lot Size $(\ln )$ & $0.562 * * *$ & $0.528 * * *$ & $0.547 * * *$ & $0.575 * * *$ \\
\hline Interior SqFt (ln) & $0.352 * * *$ & $0.448 * * *$ & $0.384 * * *$ & $0.331 * * *$ \\
\hline Stories & $0.087 * * *$ & -0.493 & $0.068 * * *$ & $0.149 * * *$ \\
\hline Age & $-0.011 * * *$ & $-0.011 * * *$ & $-0.013 * * *$ & $-0.011 * * *$ \\
\hline \multicolumn{5}{|c|}{ Neighborhood Variables $\left(L_{\mathrm{i}}\right)$} \\
\hline Median Income (ln) & $0.251 * * *$ & $0.180 * *$ & $0.244 * * *$ & $0.244 * * *$ \\
\hline Populations Density (ln) & $\mathbf{0 . 0 3 5} * * *$ & -0.009 & $\mathbf{0 . 0 5 7} * * *$ & $0.031 * *$ \\
\hline \multicolumn{5}{|l|}{ Locational Variables $\left(N_{\mathrm{i}}\right)$} \\
\hline Dist Airport (ln) & $-0.119 * * *$ & $-0.093 * * *$ & $-0.147 * * *$ & $-0.117 * * *$ \\
\hline Dist Mall (ln) & $-0.134 * * *$ & -0.043 & $-0.154 * * *$ & $-0.122 * * *$ \\
\hline Dist Arterial (ln) & $-0.095 * * *$ & -0.034 & $-0.075 * * *$ & $\mathbf{- 0 . 1 0 7} * * *$ \\
\hline Exit $300 m$ & $0.144 * * *$ & 0.106 & 0.013 & $0.131 *$ \\
\hline Exit $600 m$ & $0.100 * * *$ & 0.099 & 0.036 & $0.132 * * *$ \\
\hline Exit $900 m$ & $0.047 * *$ & 0.035 & 0.003 & 0.035 \\
\hline Station 300m & $0.610 * * *$ & $\mathrm{n} / \mathrm{a}$ & $0.598 * * *$ & $0.511 * * * *$ \\
\hline Station $600 m$ & $0.431 * * *$ & $0.787 *$ & $0.404 * * *$ & $0.416 * * *$ \\
\hline Station $900 m$ & $0.235 * * *$ & -0.079 & $0.322 * * *$ & $0.200 * * *$ \\
\hline Station $1200 m$ & $0.141 * *$ & $\mathrm{n} / \mathrm{a}$ & $\mathrm{n} / \mathrm{a}$ & 0.023 \\
\hline Hwy $150 m$ & 0.040 & $-0.207 * *$ & $0.131 *$ & 0.040 \\
\hline Hwy $250 m$ & -0.031 & $-0.277 * * *$ & 0.106 & -0.025 \\
\hline Hwy $350 m$ & 0.016 & $-0.169 *$ & $0.109 *$ & 0.026 \\
\hline Light Rail 100m & $-0.353 * * *$ & -0.060 & $-0.407 * * *$ & -0.184 \\
\hline Light Rail 200m & $-0.230 * *$ & $-0.522 * * *$ & 0.004 & -0.154 \\
\hline Light Rail 300m & $-0.283 * * *$ & $-0.908 * *$ & $-0.227 *$ & $-0.211 * *$ \\
\hline
\end{tabular}

PLUS QUARTERLY TIME DUMMIES TO CONTROL FOR REAL ESTATE MARKET

\footnotetext{
${ }^{5}$ The original model included distance variables to both the airport and the CBD, but due to multicollinearity we removed the weaker variable (CBD). The Phoenix CBD not only is well known for being weak for a metropolitan area of its size, but also has a very unusual shape, with the core downtown spreading for several miles along the Central Avenue spine. Removing the distance from CBD variable had little effect on the main results.
} 
FLUCTUATIONS

$\begin{array}{lllll}\text { Lambda }(\lambda) & 0.420 * * * & 0.427 * * * & 0.548 * * * & 0.350 * * * \\ \text { Pseudo R } \mathrm{R}^{2} & 0.91 & 0.95 & 0.91 & 0.91\end{array}$

*** Significant at 0.01 level; ** Significant at 0.05 level; * Significant at 0.10 level

In the analysis that includes all types of commercial properties, proximity to both highway exits and light rail stations, which are the variables of greatest interest, are highly significant and positively associated with the price. In addition, distance bands from light rail links are all statistically significant and negatively associated with the commercial property values as hypothesized. Highway links do not have a strong relationship with commercial property value in the full model. Thus, although the price impact of a light rail station itself is positive, the net effect of light rail on the value of commercial property located close to a station must also include the negative effect of proximity to the light rail link (Figure 4). For instance, for a property within the $300 \mathrm{~m}$ band of a light rail station (with prices 1.8 times that of similar properties located farther than $1200 \mathrm{~m}$ from a station) and also within the $100 \mathrm{~m}$ band of a light rail link ( 0.7 times that of similar properties located more than $300 \mathrm{~m}$ from a light rail link), the net sales price effect is estimated to be 1.3 times that of similar properties in the area beyond all light rail bands. However, contrary to our hypothesis, the geographical range of the impact of highway exits is less extended than that of light rail stations. Surprisingly, the benefits of being close to a light rail station are much larger than those of being close to a highway exit. 


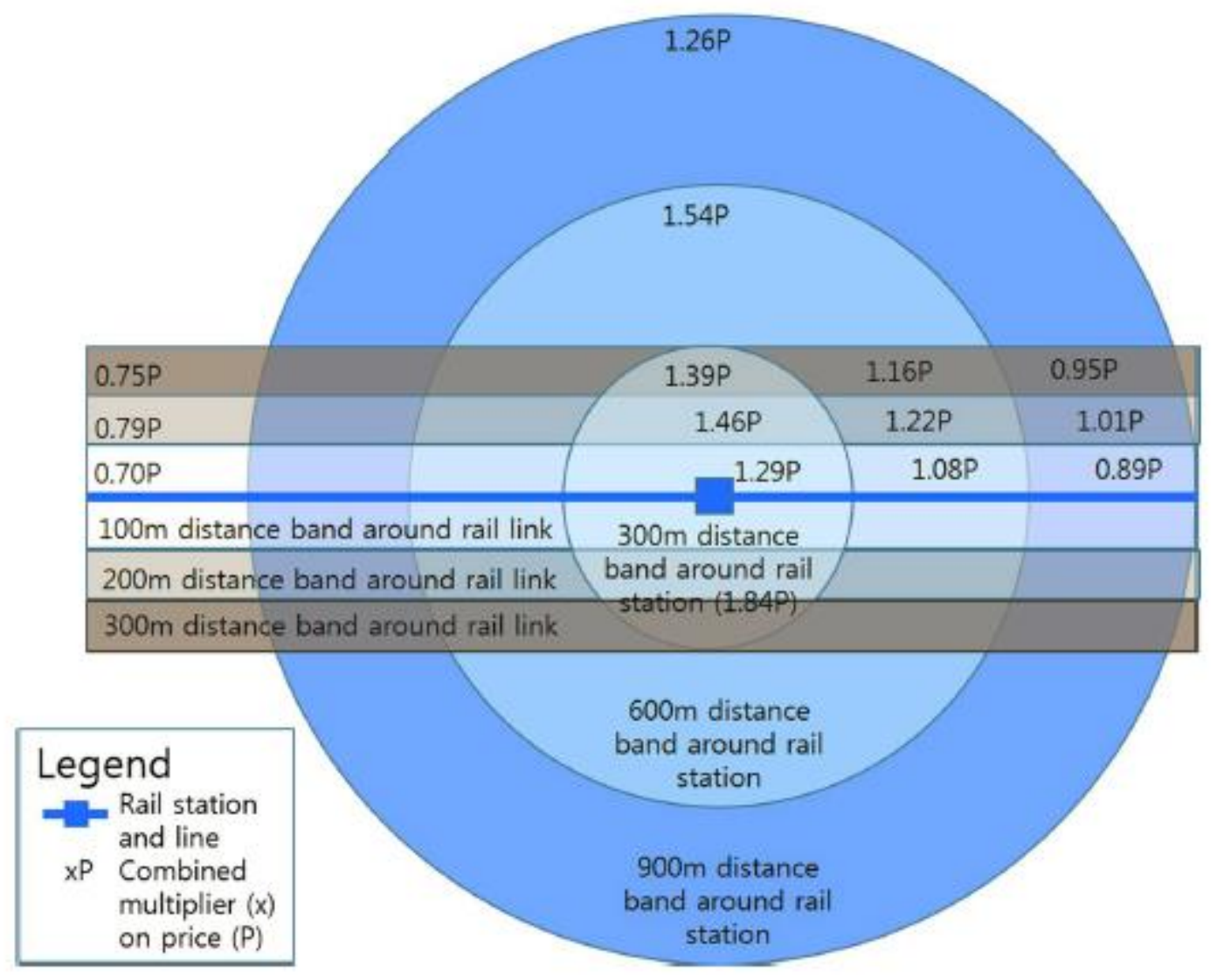

Figure 4 Estimated net price impacts near light rail stations

One possible explanation for this could be that the high speed of motorized vehicles used for highway access overcomes the physical distance barrier over quite a long range (e.g., 2-3 miles, which covers the vast majority of the properties in this dataset). This makes the road accessibility of most of our study area fairly similar, which in turn lessens the impact except for areas very close to highway exits (i.e., within $600 \mathrm{~m}$ ). In contrast, access to light rail stations is mostly by non-motorized modes (walk and bike), meaning that distance really matters for those who live near light rail stations for commuting, shopping, and other activities. Thus the price premium of being close to a light rail station accrues right at the station and declines steeply 
from there. Surprisingly, the geographical extent of the effect of light rail stations reaches much farther and the magnitude of the relationship is much larger than we expected.

Compared with the results of Seo et al.'s (2014) residential model, the coefficients of accessibility of commercial property to highway exits are much less extended geographically. Impacts of accessibility to light rail stations are also less extended for commercial than for residential property (see Figures 5 and 6). The commercial results, however, are similar to the residential results in that no disamenity "donut" effect is evident immediately surrounding the rail and highway nodes. 


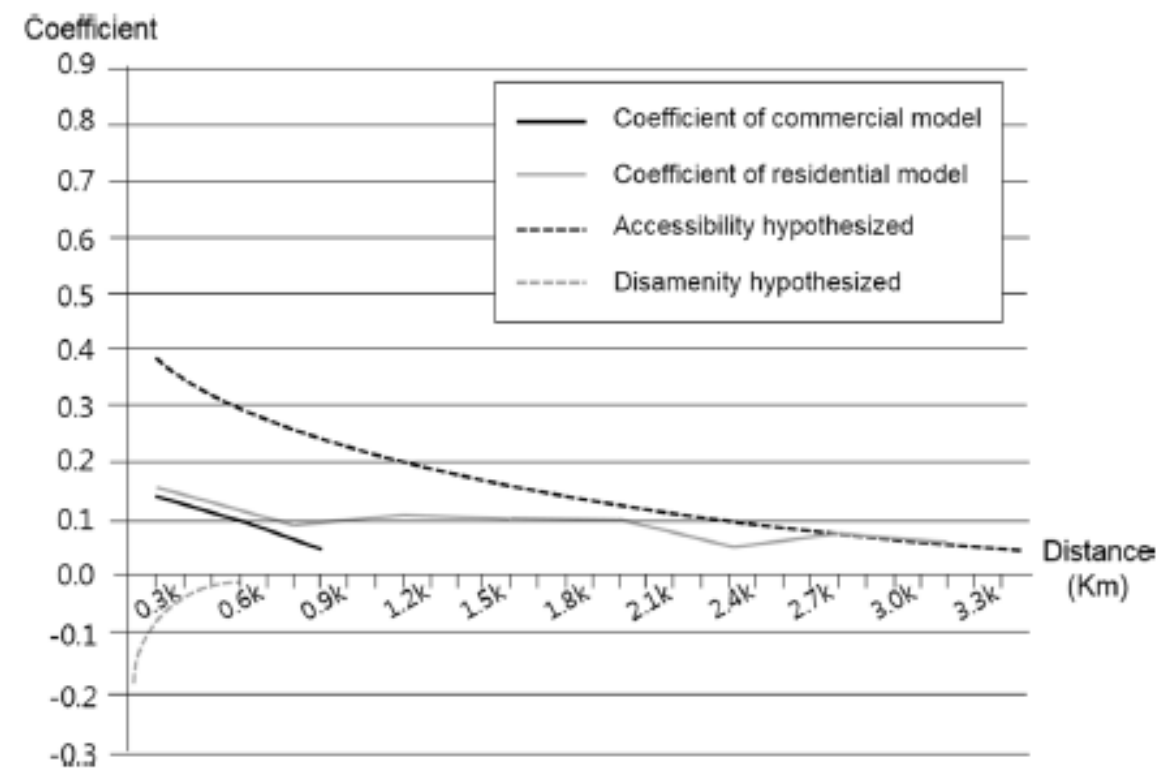

Fig. 5 Coefficients of distance to highway exits

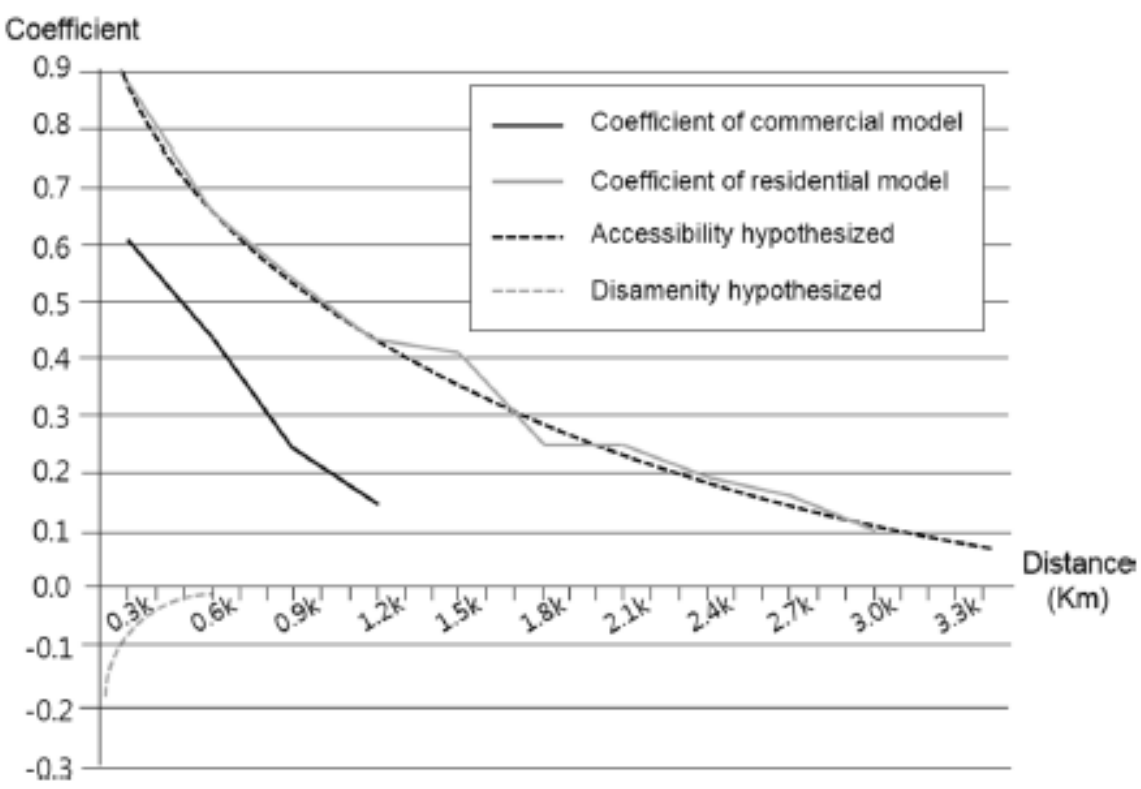

Fig. 6 Coefficients of distance to light rail stations 
The disamenity impacts of light rail links are highly significant and negatively associated with the sale price as hypothesized (Figure 7). The strength of this association may be explained by the physical location of Phoenix's light rail. Even though light rail emits no air pollution and only a small amount of noise, light rail track significantly hinders employees and customers from accessing their destinations by car because the track lies in the middle of a major arterial road. Distance from highway links is not associated significantly with the sale price of commercial properties, suggesting that commercial real estate is not especially sensitive to nuisances such as noise.

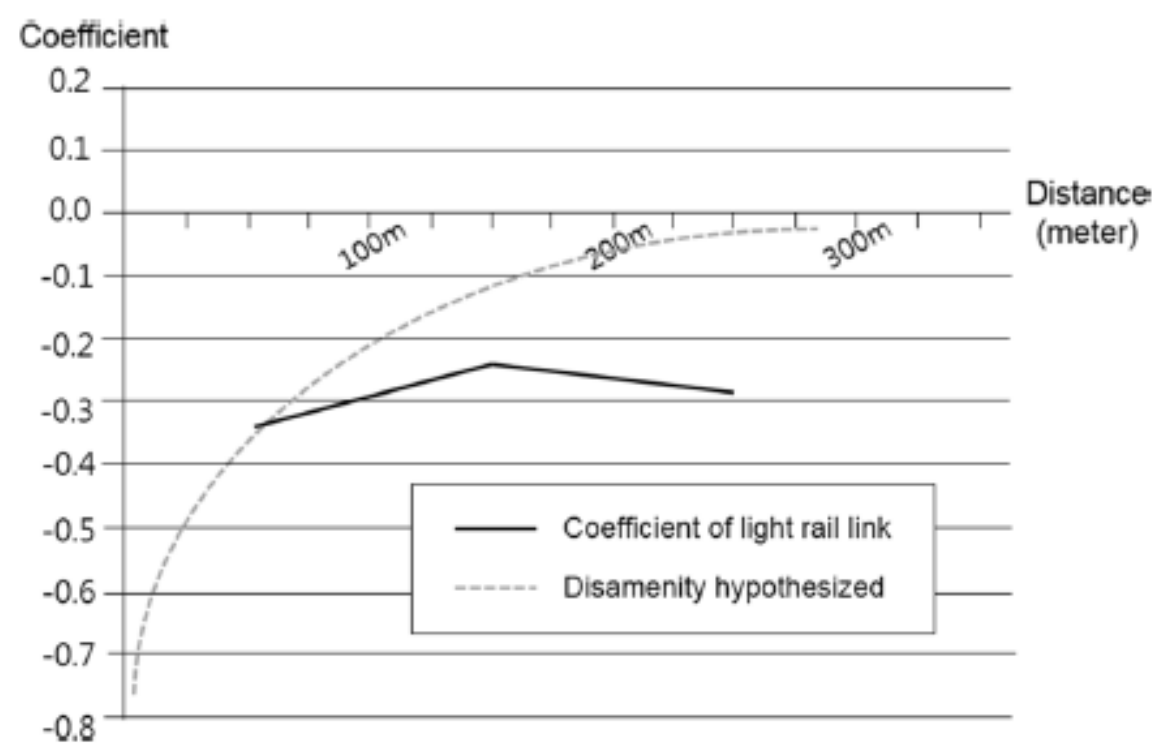

Fig. 7 Coefficients of distance to light rail link (Results of highway link in this model and residential results are not shown because coefficients were not significantly different from zero)

\section{Industrial Property}

As with the model for all commercial property, structural variables such as interior and lot square footage, and age of property are all significant at the 0.001 level, though the relationship between industrial property price and number of stories is not statistically significant (see Table 4). Turning to our variables of interest - proximity to transportation infrastructure - industrial 
property prices are negatively associated with proximity to both highway and light rail links, but largely unrelated to proximity to nodes.

\section{Office Property}

Coefficients of all structural variables in the office property model are highly statistically significant and the signs are as expected. For the neighborhood variables, both median income and population density have positive and statistically significant relationships with value. For the locational variables, proximity to the airport, shopping malls, and arterial roads are highly significant and positively associated with price. Turning to the transportation infrastructure variables, being closer to light rail stations is positively associated with the price, but proximity to highway exits is unrelated. Proximity to light rail links is negative and statistically significant at $100 \mathrm{~m}$ and $300 \mathrm{~m}$ bands, while proximity to highway links has a weak positive association with price. This finding runs counter to our hypothesis.

\section{Retail and Service Properties}

Relationships between retail and service property prices and all control variables are again statistically significant and signs are as expected. Proximity to highway exits is positively associated with price for the $300 \mathrm{~m}-600 \mathrm{~m}$ distance band, but the relationship is much weaker for the other distance bands. Proximity to light rail stations is strongly positively associated with retail and service property prices. Proximity to highway and light rail links is unrelated to property prices, with the exception of a negative association for locations between $200 \mathrm{~m}$ and 300m from a light rail line. 


\section{Conclusions}

The purpose of this paper was to identify the net effects of the nodes and links of highway and light rail transit on commercial property values. To do this, hedonic price models were built upon the foundation of De Vany's (1976) work and extended from Seo et al.'s (2014) work. The models were devised to unify a number of disparate previous findings in the hedonic literature into a single model for the commercial property market incorporating highway and light rail, nodes and links, amenities and disamenities, and distance decay for all these effects. In addition, we tested how the nodes and links of the networks differentially impact distinct commercial submarkets, and compared the results between residential and commercial hedonic models.

We hypothesized that positive impacts of accessibility accrue to the highway exits and light rail stations, while nuisance effects of noise and air pollution should emanate from the highways and light rail nodes and links. We further hypothesized that the nuisance effects would be smaller for commercial property than for residential property. Using the multiple distance bands approach, the estimated results of the spatial error regression model confirmed that distance from the nodes and links was a significant determinant of commercial property values. Plotted coefficients showed the distance decay of the amenity effect, which has a typical exponential decay curve for both highway and light rail nodes. Unexpectedly, the impacts of light rail stations on commercial property values in Phoenix are both larger and exhibit greater geographic reach than those of highway exits. For office properties, proximity to the light rail stations has a positive association with value, proximity to light rail links has a negative relationship with value, while proximity to the highway links has a positive but statistically weak relationship, contrary to expectations. For the retail and service properties, proximity to both light rail stations and highway exits has a positive association with value, while proximity to 
links has little relationship with value. While results for industrial properties were weaker than those for other commercial property types, they still confirmed that both highway and light rail links have significant and negative relationships with price. Overall, it is clear that both the magnitude and extent of the effects of distance vary based on the types of both infrastructure and of commercial property.

Comparing these commercial results with Seo et al.'s (2014) residential hedonic model, our hypothesis was confirmed that the accessibility benefits reach farther for residential property than for commercial property. Theoretically, the results of the spatial hedonic model support a bid rent theory for commercial firms that would differ in gradient and extent from the results of the residential model (Alonso 1964). Empirically, our model has tested the bid rent theory for commercial property markets' responses to real-world transportation facilities, which changes the relative location of utility maximization by improving accessibility. Together with Seo et al's (2014) residential model, this study may help unify a number of disparate previous findings in the hedonic price literature into a single, general idealized schematic model incorporating road and rail, nodes and links, amenities and disamenities, and the distance decay functions for all of these effects.

The results of this study may be useful to commercial property buyers to identify the location where the net benefit of accessibility to transportation infrastructure is maximized. Commercial property construction companies may be able to decide where to build developments for maximizing profit and sales by predicting where markets will most reward location. City authorities may also use these results as a basis for location value capture-based funding for transportation projects, which depend on knowing the size and extent of benefits to nearby property. 
While these results provide a first look at the value of proximity to infrastructure for commercial properties in Phoenix, these values likely vary across space as well as between property types. A productive avenue for future research, therefore, might be the application of techniques such as geographically weighted regression to these data, which allow for estimation of value effects that vary across space. 


\section{References}

Alonso, W.: Location and land use. Toward a general theory of land rent. Harvard University Press (1964)

Anderson, J. E.: Tax increment financing: Municipal adoption and growth. National Tax Journal. $43,155-163(1990)$

Anselin, L.: Spatial econometrics: Methods and models, Boston. Kluwer Academic Publishers (1988)

Anselin, L., Rey, S. J.: Modern Spatial Econometrics in Practice: A Guide to GeoDa, GeoDaSpace and PySAL (2014)

Arizona Department of Revenue.: Computer assisted mass appraisal systems - residential property. https://www.azdor.gov/Portals/0/Brochure/546.pdf (2009). Accessed 04 February 2015

Bateman, I., Day, B., Lake, L., Lovett. A.: The effect of road traffic on residential property values: A literature review and hedonic pricing study 207, Scottish Executive (2001)

Billings, S. B.: Estimating the value of a new transit option. Regional Science and Urban Economics. 41(6), 525-536 (2011)

Bollinger, C. R., Ihlanfeldt, K. R., Bowes, D. R.: Spatial variation in office rents within the Atlanta region. Urban Studies. 35(7), 1097-1118 (1998)

Brennan, T. P., Cannaday, R. E., Colwell, P. F.: Office rent in the Chicago CBD. Real Estate Economics. 12(3), 243-260 (1984)

Cervero, R., Duncan, M.: Transit's value-added effects: light and commuter rail services and commercial land values. Transportation Research Record: Journal of the Transportation Research Board. 1805(1), 8-15 (2002)

Champ, P. A., Bolye, K. J., Brown, T. C.: A primer on nonmarket valuation. Boston: Kluwer Academic Publishers (2003)

Clapp, J. M.: The intrametropolitan location of office activities. Journal of Regional Science. 20(3), 387-399 (1980)

Colliers International.: Research \& Forecast Report.Q3 Greater Phoenix | Industrial. http://www.colliers.com//media/files/marketresearch/unitedstates/markets/greater\%20phoenix/q3-2015/q3-2015greater-phoenix-industrial-market-report.pdf (2015). Accessed 30 November 2015

Damm, D., Lerman, S. R., Lerner-Lam, E., Young, J.: Response of urban real estate values in anticipation of the Washington Metro. Journal of Transport Economics and Policy. 315$336(1980)$

Debrezion, G., Pels, E., Rietveld, P.: The impact of railway stations on residential and commercial property value: a meta-analysis. The Journal of Real Estate Finance and Economics. 35(2), 161-180 (2007) 
De Vany, A. S.: An economic model of airport noise pollution in an urban environment. In S.A.Y. Lin, ed., Theory and Measurement of Economic Externalities. New York: Academic Press. 205-214 (1976)

Dunse, N., Jones, C.: A hedonic price model of office rents. Journal of Property Valuation and Investment. 16(3), 297-312 (1998)

Glascock, J. L., Jahanian, S., Sirmans, C. F.: An analysis of office market rents: some empirical evidence. Real Estate Economics. 18(1), 105-119 (1990)

Golub, A., Guhathakurta, S., Sollapuram, B.: Spatial and temporal capitalization effects of light rail in Phoenix: From conception, planning, and construction to operation. Journal of Planning Education and Research. 32(4), 415-429 (2012)

Ihlanfeldt, K. R., \& Martinez-Vazquez, J.: Alternative value estimates of owner-occupied housing: evidence on sample selection bias and systematic errors. Journal of Urban Economics. 20(3), 356-369 (1986)

Landis, J., Loutzenheiser, D.: BART Access and Office Building Performance. University of California Transportation Center (1995)

LeSage, J., Pace, R. K.: Introduction to spatial econometrics. CRC press (2009)

Mills, E. S.: Office rent determinants in the Chicago area. Real Estate Economics. 20(2), 273287 (1992)

Nelson, J. P.: Highway noise and property values: A survey of recent evidence. Journal of Transport Economics and Policy. 16(2), 117-138 (1982)

Partridge, M. D., Boarnet, M., Brakman, S., and Ottaviano, G. Introduction: whither spatial econometrics? Journal of Regional Science. 52(2), 167-171 (2012)

Peterson, G. E.: Unlocking land values to finance urban infrastructure. Washington, DC: The World Bank (2009)

Ryan, S.: The value of access to highways and light rail transit: Evidence for industrial and office firms. Urban Studies. 42(4), 751-764 (2005)

Seo, K., Golub, A., Kuby, M.: Combined impacts of highways and light rail transit on residential property values: a spatial hedonic price model for Phoenix, Arizona. Journal of Transport Geography. 41, 53-62 (2014)

Sivitanidou, R.: Urban spatial variations in office-commercial rents: the role of spatial amenities and commercial zoning. Journal of Urban Economics. 38(1), 23-49 (1995)

Sivitanidou, R.: Do office-commercial firms value access to service employment centers? A hedonic value analysis within polycentric Los Angeles. Journal of Urban Economics. 40(2), 125-149 (1996)

Sivitanidou, R., Sivitanides, P. The intrametropolitan distribution of R\&D activities: theory and empirical evidence. Journal of Regional Science. 35(3), 391-416 (1995) 
U.S. Census Bureau.: State \& County QuickFacts: Phoenix, Arizona. http://quickfacts.census.gov/qfd/states/04/0455000.html (2010). Accessed 10 May 2013

Vessali, K. V.: Land use impacts of rapid transit: A review of empirical literature. Berkeley Planning Journal. 11,71-105 (1996)

Weber, A., Friedrich, C. J.: Alfred Weber's theory of the location of industries. University of Chicago Press (1929)

Weinberger, R. R. Light rail proximity: Benefit or detriment in the case of Santa Clara County, California?. Transportation Research Record: Journal of the Transportation Research Board. 1747(1), 104-113 (2001)

Wheaton, W. C., Torto, R. G.: Office rent indices and their behavior over time. Journal of Urban Economics. 35, 121-139 (1994)

Zhao, Z., Iacono, M., Lari, A., \& Levinson, D.: Value capture for transportation finance. Procedia-Social and Behavioral Sciences. 48, 435-448 (2012) 


\section{Figure Captions}

Figure 1 Conceptual framework for net benefit of combined impacts of accessibility and disamenities (source: Seo et al. 2014 - modified for commercial property)

Figure 2 Study area and distribution of all commercial properties

Figure 3 Section of central Phoenix illustrating of multiple distance band approach around light rail links and stations and freeway links and exits. When rings around nearby stations and exits overlap, commercial properties are assigned to the distance band of their closest station. Note that some properties fall into a distance band for each of the four types of transport infrastructure where light rail lines cross highways and stations and exits are located nearby.

Figure 4 Estimated net price impacts near light rail stations

Figure 5 Coefficients of distance to highway exits

Figure 6 Coefficients of distance to light rail stations

Figure 7 Coefficients of distance to light rail link (Results of highway link in this model and residential results are not shown because coefficients were not significantly different from zero) 


\section{Appendix}

Table 5 Estimation results, all commercial property sales $(\mathrm{N}=3,337)$

\begin{tabular}{|c|c|c|c|c|c|c|c|}
\hline Variable & $\begin{array}{l}\text { OLS } \\
\text { Coefficients }\end{array}$ & S.E. & p-value & $\begin{array}{l}\text { Spatial Error } \\
\text { Coefficients }\end{array}$ & S.E. & p-value & VIF \\
\hline (Constant) & 4.174 & 0.267 & 0.000 & 3.955 & 0.358 & 0.000 & $\mathrm{n} / \mathrm{a}$ \\
\hline \multicolumn{8}{|l|}{ Structural Variables $\left(S_{\mathrm{i}}\right)$} \\
\hline Lot Size $(\ln )$ & 0.576 & 0.005 & 0.000 & 0.562 & 0.009 & 0.000 & 1.45 \\
\hline Interior $S q F t(\ln )$ & 0.334 & 0.007 & 0.000 & 0.352 & 0.013 & 0.000 & 1.97 \\
\hline Stories & 0.079 & 0.007 & 0.000 & 0.087 & 0.012 & 0.000 & 1.40 \\
\hline Age & -0.012 & $5 \mathrm{E}-04$ & 0.000 & -0.011 & 0.001 & 0.000 & 1.65 \\
\hline \multicolumn{8}{|c|}{ Neighborhood Variables $\left(\mathbf{L}_{\mathrm{i}}\right)$} \\
\hline Median Income (ln) & 0.250 & 0.018 & 0.000 & 0.251 & 0.023 & 0.000 & 1.51 \\
\hline Population Density (ln) & 0.034 & 0.008 & 0.000 & 0.035 & 0.010 & 0.000 & 1.29 \\
\hline \multicolumn{8}{|l|}{ Locational Variables $\left(\mathbf{N}_{\mathrm{i}}\right)$} \\
\hline Dist Airport (ln) & -0.123 & 0.013 & 0.000 & -0.119 & 0.015 & 0.000 & 1.38 \\
\hline Dist Mall (ln) & -0.153 & 0.009 & 0.000 & -0.134 & 0.013 & 0.000 & 1.13 \\
\hline Dist Arterial (ln) & -0.085 & 0.009 & 0.000 & -0.095 & 0.011 & 0.000 & 1.52 \\
\hline Exit $300 m$ & 0.211 & 0.044 & 0.000 & 0.144 & 0.053 & 0.006 & 2.03 \\
\hline Exit $600 m$ & 0.107 & 0.026 & 0.000 & 0.100 & 0.030 & 0.001 & 1.66 \\
\hline Exit $900 m$ & 0.054 & 0.021 & 0.011 & 0.047 & 0.024 & 0.045 & 1.19 \\
\hline Station $300 m$ & 0.628 & 0.068 & 0.000 & 0.610 & 0.102 & 0.000 & 2.23 \\
\hline Station 600m & 0.434 & 0.041 & 0.000 & 0.431 & 0.063 & 0.000 & 1.44 \\
\hline Station $900 m$ & 0.244 & 0.041 & 0.000 & 0.235 & 0.067 & 0.000 & 1.10 \\
\hline Station $1200 m$ & 0.105 & 0.043 & 0.014 & 0.141 & 0.056 & 0.012 & 1.12 \\
\hline Hwy 150 m & 0.019 & 0.042 & 0.655 & 0.040 & 0.046 & 0.386 & 1.60 \\
\hline Hwy $250 m$ & -0.074 & 0.038 & 0.051 & -0.031 & 0.042 & 0.456 & 1.72 \\
\hline Hwy $350 m$ & -0.001 & 0.037 & 0.981 & 0.016 & 0.038 & 0.680 & 1.37 \\
\hline Light Rail 100m & -0.334 & 0.059 & 0.000 & -0.353 & 0.089 & 0.000 & 1.92 \\
\hline Light Rail 200m & -0.192 & 0.071 & 0.006 & -0.230 & 0.100 & 0.021 & 1.32 \\
\hline Light Rail 300m & -0.286 & 0.069 & 0.000 & -0.283 & 0.076 & 0.000 & 1.41 \\
\hline \multicolumn{8}{|c|}{ PLUS QUARTERLY TIME DUMMIES TO CONTROL FOR REAL ESTATE MARKET FLUCTUATIONS } \\
\hline $\operatorname{Lambda}(\boldsymbol{\lambda})$ & $\mathrm{n} / \mathrm{a}$ & $\mathrm{n} / \mathrm{a}$ & $\mathrm{n} / \mathrm{a}$ & 0.420 & 0.025 & 0.000 & $\mathrm{n} / \mathrm{a}$ \\
\hline Adjusted $\mathbf{R}^{2}$ / Pseudo $\mathbf{R}^{2}$ & 0.91 & & & 0.91 & & & \\
\hline
\end{tabular}


Table 6 Estimation results of the industrial properties ( $N=357)$

\begin{tabular}{|c|c|c|c|c|c|c|c|}
\hline Variable & $\begin{array}{l}\text { OLS } \\
\text { Coefficients }\end{array}$ & S.E. & p-value & $\begin{array}{l}\text { Spatial Error } \\
\text { Coefficients }\end{array}$ & S.E. & p-value & VIF \\
\hline (Constant) & 3.050 & 0.913 & 0.001 & 3.811 & 1.024 & 0.000 & $\mathrm{n} / \mathrm{a}$ \\
\hline \multicolumn{8}{|l|}{ Structural Variables $\left(S_{\mathrm{i}}\right)$} \\
\hline Lot Size (ln) & 0.538 & 0.013 & 0.000 & 0.528 & 0.020 & 0.000 & 2.18 \\
\hline Interior $S q F t(\ln )$ & 0.444 & 0.025 & 0.000 & 0.448 & 0.032 & 0.000 & 1.88 \\
\hline Stories & -0.593 & 0.390 & 0.130 & -0.493 & 0.445 & 0.268 & 1.83 \\
\hline Age & -0.010 & 0.002 & 0.000 & -0.011 & 0.002 & 0.000 & 2.32 \\
\hline \multicolumn{8}{|c|}{ Neighborhood Variables $\left(L_{\mathrm{i}}\right)$} \\
\hline Median Income (ln) & 0.222 & 0.050 & 0.000 & 0.180 & 0.070 & 0.010 & 1.48 \\
\hline Population Density (ln) & -0.021 & 0.020 & 0.288 & -0.009 & 0.021 & 0.687 & 1.80 \\
\hline \multicolumn{8}{|l|}{ Locational Variables $\left(N_{\mathrm{i}}\right)$} \\
\hline Dist Airport (ln) & -0.062 & 0.036 & 0.085 & -0.093 & 0.033 & 0.005 & 2.49 \\
\hline Dist Mall (ln) & -0.015 & 0.033 & 0.656 & -0.043 & 0.037 & 0.238 & 1.83 \\
\hline Dist Arterial (ln) & -0.037 & 0.025 & 0.141 & -0.034 & 0.024 & 0.152 & 1.46 \\
\hline Exit $300 m$ & 0.174 & 0.123 & 0.159 & 0.106 & 0.091 & 0.242 & 1.60 \\
\hline Exit $600 m$ & 0.133 & 0.062 & 0.034 & 0.099 & 0.078 & 0.204 & 3.11 \\
\hline Exit $900 m$ & 0.022 & 0.055 & 0.684 & 0.035 & 0.051 & 0.494 & 1.58 \\
\hline Station $600 m$ & 0.956 & 0.257 & 0.000 & 0.787 & 0.438 & 0.072 & 3.90 \\
\hline Station $900 m$ & -0.037 & 0.165 & 0.820 & -0.079 & 0.229 & 0.731 & 1.29 \\
\hline Hwy $150 m$ & -0.255 & 0.090 & 0.005 & -0.207 & 0.083 & 0.013 & 2.10 \\
\hline Hwy $250 m$ & -0.348 & 0.076 & 0.000 & -0.277 & 0.083 & 0.001 & 2.70 \\
\hline Hwy 350m & -0.209 & 0.076 & 0.007 & -0.169 & 0.091 & 0.063 & 2.33 \\
\hline Light Rail 100m & -0.095 & 0.186 & 0.611 & -0.060 & 0.167 & 0.721 & 1.23 \\
\hline Light Rail 200m & -0.441 & 0.150 & 0.004 & -0.522 & 0.138 & 0.000 & 2.86 \\
\hline Light Rail 300m & -0.747 & 0.325 & 0.022 & -0.908 & 0.397 & 0.022 & 2.53 \\
\hline \multicolumn{8}{|c|}{ PLUS QUARTERLY TIME DUMMIES TO CONTROL FOR REAL ESTATE MARKET FLUCTUATIONS } \\
\hline Lambda $(\boldsymbol{\lambda})$ & $\mathrm{n} / \mathrm{a}$ & $\mathrm{n} / \mathrm{a}$ & $\mathrm{n} / \mathrm{a}$ & 0.427 & 0.068 & 0.000 & $\mathrm{n} / \mathrm{a}$ \\
\hline Adjusted $\mathbf{R}^{2}$ / Pseudo $\mathbf{R}^{2}$ & 0.94 & & & 0.95 & & & \\
\hline
\end{tabular}


Table 7 Estimation results of the office properties $(\mathrm{N}=1,150)$

\begin{tabular}{|c|c|c|c|c|c|c|c|}
\hline Variable & $\begin{array}{l}\text { OLS } \\
\text { Coefficients }\end{array}$ & S.E. & p-value & $\begin{array}{l}\text { Spatial Error } \\
\text { Coefficients }\end{array}$ & S.E. & p-value & VIF \\
\hline (Constant) & 4.338 & 0.556 & 0.000 & 4.186 & 0.675 & 0.000 & $\mathrm{n} / \mathrm{a}$ \\
\hline \multicolumn{8}{|l|}{ Structural Variables $\left(S_{\mathrm{i}}\right)$} \\
\hline Lot Size (ln) & 0.565 & 0.010 & 0.000 & 0.547 & 0.017 & 0.000 & 1.76 \\
\hline Interior SqFt (ln) & 0.363 & 0.015 & 0.000 & 0.384 & 0.028 & 0.000 & 2.46 \\
\hline Stories & 0.053 & 0.009 & 0.000 & 0.068 & 0.018 & 0.000 & 1.98 \\
\hline Age & -0.013 & 0.001 & 0.000 & -0.013 & 0.001 & 0.000 & 2.14 \\
\hline \multicolumn{8}{|c|}{ Neighborhood Variables $\left(L_{\mathrm{i}}\right)$} \\
\hline Median Income (ln) & 0.237 & 0.036 & 0.000 & 0.244 & 0.044 & 0.000 & 1.77 \\
\hline Population Density (ln) & 0.057 & 0.016 & 0.000 & 0.057 & 0.018 & 0.001 & 1.31 \\
\hline \multicolumn{8}{|l|}{ Locational Variables $\left(N_{\mathrm{i}}\right)$} \\
\hline Dist Airport $(\ln )$ & -0.146 & 0.024 & 0.000 & -0.147 & 0.025 & 0.000 & 1.38 \\
\hline Dist Mall (ln) & -0.174 & 0.019 & 0.000 & -0.154 & 0.027 & 0.000 & 1.17 \\
\hline Dist Arterial (ln) & -0.062 & 0.016 & 0.000 & -0.075 & 0.017 & 0.000 & 1.40 \\
\hline Exit $300 m$ & 0.085 & 0.088 & 0.334 & 0.013 & 0.092 & 0.887 & 2.38 \\
\hline Exit $600 m$ & 0.014 & 0.048 & 0.774 & 0.036 & 0.055 & 0.507 & 1.57 \\
\hline Exit $900 m$ & 0.011 & 0.037 & 0.765 & 0.003 & 0.042 & 0.951 & 1.24 \\
\hline Station $300 m$ & 0.645 & 0.116 & 0.000 & 0.598 & 0.147 & 0.000 & 3.02 \\
\hline Station $600 m$ & 0.415 & 0.067 & 0.000 & 0.404 & 0.083 & 0.000 & 1.47 \\
\hline Station 900m & 0.334 & 0.074 & 0.000 & 0.322 & 0.113 & 0.004 & 1.08 \\
\hline Hwy $150 m$ & 0.103 & 0.083 & 0.213 & 0.131 & 0.075 & 0.081 & 1.94 \\
\hline Hwy $250 m$ & 0.104 & 0.080 & 0.191 & 0.106 & 0.083 & 0.200 & 1.80 \\
\hline Hwy $350 m$ & 0.074 & 0.068 & 0.280 & 0.109 & 0.064 & 0.089 & 1.26 \\
\hline Light Rail 100m & -0.456 & 0.106 & 0.000 & -0.407 & 0.119 & 0.001 & 2.43 \\
\hline Light Rail 200m & 0.035 & 0.156 & 0.820 & 0.004 & 0.144 & 0.976 & 1.32 \\
\hline Light Rail 300m & -0.294 & 0.118 & 0.013 & -0.227 & 0.123 & 0.066 & 1.69 \\
\hline \multicolumn{8}{|c|}{ PLUS QUARTERLY TIME DUMMIES TO CONTROL FOR REAL ESTATE MARKET FLUCTUATIONS } \\
\hline $\operatorname{Lambda}(\boldsymbol{\lambda})$ & $\mathrm{n} / \mathrm{a}$ & $\mathrm{n} / \mathrm{a}$ & $\mathrm{n} / \mathrm{a}$ & 0.548 & 0.044 & 0.000 & $\mathrm{n} / \mathrm{a}$ \\
\hline Adjusted $\mathbf{R}^{2}$ / Pseudo $\mathbf{R}^{2}$ & 0.90 & & & 0.91 & & & \\
\hline
\end{tabular}


Table 8 Estimation results of retail and service properties $(\mathrm{N}=1,830)$

\begin{tabular}{|c|c|c|c|c|c|c|c|}
\hline Variable & $\begin{array}{l}\text { OLS } \\
\text { Coefficients }\end{array}$ & S.E. & p-value & $\begin{array}{l}\text { Spatial Error } \\
\text { Coefficients }\end{array}$ & S.E. & p-value & VIF \\
\hline (Constant) & 3.854 & 0.337 & 0.000 & 3.968 & 0.461 & 0.000 & $\mathrm{n} / \mathrm{a}$ \\
\hline \multicolumn{8}{|l|}{ Structural Variables $\left(S_{\mathrm{i}}\right)$} \\
\hline Lot Size $(\ln )$ & 0.596 & 0.008 & 0.000 & 0.575 & 0.016 & 0.000 & 1.71 \\
\hline Interior SqFt (ln) & 0.314 & 0.009 & 0.000 & 0.331 & 0.018 & 0.000 & 2.01 \\
\hline Stories & 0.164 & 0.022 & 0.000 & 0.149 & 0.033 & 0.000 & 1.18 \\
\hline Age & -0.011 & 0.001 & 0.000 & -0.011 & 0.001 & 0.000 & 1.52 \\
\hline \multicolumn{8}{|c|}{ Neighborhood Variables $\left(L_{\mathrm{i}}\right)$} \\
\hline Median Income (ln) & 0.244 & 0.023 & 0.000 & 0.244 & 0.028 & 0.000 & 1.59 \\
\hline Population Density $(\ln )$ & 0.038 & 0.012 & 0.001 & 0.031 & 0.014 & 0.021 & 1.39 \\
\hline \multicolumn{8}{|l|}{ Locational Variables $\left(N_{\mathrm{i}}\right)$} \\
\hline Dist Airport (ln) & -0.120 & 0.017 & 0.000 & -0.117 & 0.020 & 0.000 & 1.43 \\
\hline Dist Mall (ln) & -0.127 & 0.012 & 0.000 & -0.122 & 0.016 & 0.000 & 1.26 \\
\hline Dist Arterial (ln) & -0.100 & 0.012 & 0.000 & -0.107 & 0.016 & 0.000 & 1.62 \\
\hline Exit $300 m$ & 0.145 & 0.058 & 0.012 & 0.131 & 0.068 & 0.055 & 2.25 \\
\hline Exit $600 m$ & 0.135 & 0.033 & 0.000 & 0.132 & 0.039 & 0.001 & 1.59 \\
\hline Exit $900 m$ & 0.041 & 0.030 & 0.166 & 0.035 & 0.031 & 0.252 & 1.21 \\
\hline Station $300 m$ & 0.583 & 0.091 & 0.000 & 0.511 & 0.146 & 0.000 & 1.94 \\
\hline Station 600m & 0.419 & 0.055 & 0.000 & 0.416 & 0.089 & 0.000 & 1.46 \\
\hline Station $900 m$ & 0.205 & 0.050 & 0.000 & 0.200 & 0.071 & 0.005 & 1.13 \\
\hline Station $1200 m$ & 0.041 & 0.054 & 0.447 & 0.023 & 0.051 & 0.648 & 1.15 \\
\hline Hwy $150 m$ & 0.055 & 0.057 & 0.335 & 0.040 & 0.066 & 0.542 & 1.58 \\
\hline$H w y 250 m$ & -0.033 & 0.052 & 0.529 & -0.025 & 0.054 & 0.643 & 1.83 \\
\hline Hwy $350 m$ & 0.030 & 0.051 & 0.553 & 0.026 & 0.053 & 0.631 & 1.44 \\
\hline Light Rail 100m & -0.170 & 0.075 & 0.024 & -0.184 & 0.112 & 0.100 & 1.73 \\
\hline Light Rail 200m & -0.180 & 0.090 & 0.044 & -0.154 & 0.144 & 0.287 & 1.41 \\
\hline Light Rail 300m & -0.289 & 0.092 & 0.002 & -0.211 & 0.104 & 0.043 & 1.32 \\
\hline \multicolumn{8}{|c|}{ PLUS QUARTERLY TIME DUMMIES TO CONTROL FOR REAL ESTATE MARKET FLUCTUATIONS } \\
\hline $\operatorname{Lambda}(\boldsymbol{\lambda})$ & $\mathrm{n} / \mathrm{a}$ & $\mathrm{n} / \mathrm{a}$ & $\mathrm{n} / \mathrm{a}$ & 0.350 & 0.037 & 0.000 & $\mathrm{n} / \mathrm{a}$ \\
\hline Adjusted $\mathbf{R}^{2}$ / Pseudo $\mathbf{R}^{2}$ & 0.91 & & & 0.91 & & & \\
\hline
\end{tabular}

